УДК $378.147+81 ’ 276.6$

DOI:

Любов Павловська, старший викладач, кафедри теорії, практики та перекладу німецької мови, факультет лінгвістики

Національного технічного університету Украӥни

“Киїський політехнічний інститут імені I. Сікорського”

\title{
ВЗАЕМОДІЯ СТУДЕНТА ТА ВИКЛАДАЧА ЯК ОДИН ЗІ ШЛЯХІВ ОПТИМІЗАЦІї НАВЧАННЯ ІНОЗЕМНИХ МОВ В ІНФОРМАЦІЙНОМУ СУСПІЛЬСТВІ
}

У фокусі уваги статті - зворотний зв'язок для забезпечення ефективної взаємодії студента та викладача в рамках студентоорієнтованого підходу. 3 урахуванням вимог нормативної системи вказується на необхідність для активізації залучення та підвищення якості викладання працювати над створенням відповідних умов та можливостей для подальщого розвитку рівня педагогічних навичок $і$ кар'єрного зростання викладачів.

Зауважується про важливість зворотного зв'язку при формуванні індивідуальної освітньої траєкторії студента в процесі навчання у дистанційному форматі, зокрема при навчанні іноземної мови.

Ключові слова: стратегї̈ навчання; зворотний зв'язок; практика викладання та навчання; мотиваційні стратегї; німеиька мова.

תim. 12.

Liubov Pavlovska, Senior Lecturer of the Theory, Practice and Translation of German Department, Faculty of Linguistics National Technical University of Ukraine "Kyiv Ihor Sikorsky Polytechnic Institute"

\section{STUDENT-TEACHER TEAMWORKAS ONE OF THE WAYS TO OPTIMIZE TEACHING FOREIGN LANGUAGES IN THE INFORMATION SOCIETY}

The focus of the article is on the feedback that students receive during their studies in the institution, including in foreign language classes. Within studies in the institution, feedback is seen as facilitative in that it involves provision of comments and suggestions to enable students to make their own revisions to the educational process. There is a substantial and growing body of research in higher education contexts considering feedback and its importance in student learning. Enhancing the quality of feedback to university students needs to be considered against the backdrop of the massification and consumerization of higher education. Feedback is not the sole responsibility of the lecturer. It is obvious that the student should be an active seeker, user, and contributor to the feedback process.

In Ukraine, nationally, attention is being given to the development of a quality assurance system for higher education. There are encouraging indicators of infrastructure changes in Ukraine to address teaching quality, including teaching foreign languages, in line with the European standards. Applying active learning techniques increases the role of organized and systematic feedback between all participants in the learning process. It is of special interest how feedback impacts on the development of identity and professional self-assessment for both the lecturer and student. Feedback is seen as a crucial way to development of students so that they can monitor, evaluate and regulate their own learning. Within a regulatory system to ensure standards, in order to increase engagement and improve teaching excellence, it is necessary to create the appropriate conditions for opportunities to improve the level of teaching skills and career advancement of teachers. Contemporary conditions require new priorities for the activity of a teacher of higher education. In a difficult time of change, during an ongoing pandemic, the role of the teacher increases significantly. As an expert and consultant, the teacher helps students to continue their studies in a distance format, contributes to the formation of an individual educational path for each student.

In addition, teachers must focus on innovative approaches to teaching students, participate in scientific research, and orient the educational process in accordance with the growing demands of the labor market.

Keywords: learning strategies; feedback; teaching and learning practice; motivational strategies; German language.

П

остановка проблеми в загальному вигляді та обгрунтування її актуальності. У наші дні дедалі зростає кількість студентів, які, на відміну від попередників, більш мотивовані вивчати іноземні мови, розуміють їх цінність для майбутнього та готові інвестувати в освіту. Багато студентів здатні адаптувати свій спосіб вчитися до нових реалій життя, адже система освіти в Україні не завжди встигає задовольняти виклики сучасності. 


\section{ВЗАЄМОДІЯ СТУДЕНТА ТА ВИКЛАДАЧА ЯКОДИНЗІ ШЛЯХІВ ОПТИМІЗАЦЇ̈ НАВЧАННЯ ІНОЗЕМНИХ МОВ В ІНФОРМАЦИЙНОМУ СУСПІЛЬСТВІ}

Можна з упевненістю зазначити, що сьогоднішні студенти є більш обізнаними із новітніми інформаційно-комунікаційними технологіями та вміють працювати не тільки 3 офісними додатками, але й з численними системними, інструментальними та прикладними програмами.

На сьогодні перед викладачами ЗВО постає складне завдання $з$ метою поліпшення якості надання освітніх послуг сприяти розвитку у студентів навичок системного мислення, міжгалузевої комунікації, вміння працювати в умовах невизначеності, володіння декількома мовами, формуванню мультикультурної компетентності, мультифункціональної особистості, екологічності мислення [6, 30]. Мати кваліфікацію спеціаліста, навіть високого рівня, лише у своїй галузі для сучасного випускника закладу вищої освіти вже недостатньо. Стрімкий розвиток міжнародних науково-технічних зв'язків, необхідність розширення ділових контактів та зміцнення культурних зв'язків потребують володіння іноземною мовою. Знання кількох іноземних мов безумовно додає цінності майбутнім фахівцям на ринку праці.

Відомо, що німецька мова у науковій сфері $€$ другою за значимістю. Німеччина займає третє місце у світі за обсягами внесків у науководослідні розробки [7]. Як показує дослідження "Deutsch als Fremdsprache weltweit" від 2020 року, понад 15,4 мільйона людей у всьому світі вивчають німецьку мову як іноземну [10]. На сьогодні у світі 1, 27 мільйона студентів вивчають німецьку мову у закладах вищої освіти. Міністерство закордонних справ Німеччини та організації-партнери акцентують особливу увагу на фінансуванні підготовки й підвищенні кваліфікації викладачів, адже зі зростанням попиту на німецьку мову у багатьох країнах зростає дефіцит викладачів німецької мови [10]. Більшість тих, хто вивчають німецьку мову, проживають у Європі. Загалом на сьогодні їхня кількість становить близько 9,4 мільйона осіб [7].

Вивчення німецької як мови загальнотехнічного спрямування, для спеціальних цілей або як другої іноземної мови $\epsilon$ засобом формування міжкультурноїпрофесійно-орієнтованої комунікативної компетенції, яка в подальшому допомагатиме випускнику інтегруватися у міжнародне професійне та наукове середовище, підвищить його конкурентоспроможність на ринку праці.

Аналіз останніх досліджень і публікацій. Вагомий вплив на вивчення та навчання німецької мови як другої іноземної або як загальнотехнічної мови має особистість викладача. Саме від цього, рівня його професійної компетенції залежить організація власне процесу навчання. Поліпшенню якості викладання та навчання, підвищенню рівня залученості студентів до навчального процесу сприяє наявність зворотного зв'язку між суб'єктами освітнього процесу, зокрема, між викладачем та студентами. Проблемі зворотного зв’язку у вищій освіті присвячено досить багато соціально-педагогічних та психологічних досліджень вітчизняних та зарубіжних викладачів й науковців (М. Кур'ян, Є. Дідович, Т. Пєтухова, К. Заруцька, Г. Кушкарбаєва, C. Evans, E. Ball, S. Hartung та ін.).

К. Заруцька досліджувала питання про те, яким має бути зворотний зв'язок, щоб після його отримання студент коригував навчальну поведінку та поліпшував результати своєї роботи [2].

С. Хартунг вказує на занадто низький пріоритет зворотного зв'язку у німецьких університетах [12]. Вона зазначає, що: “Через домінуючий структурно-орієнтований підхід у навчанні та екзаменах поки що було мало підстав для зворотного зв'язку" [12]. Учена робить висновок, що ситуація зі зворотним зв'язком змінюється у кращий бік разом із попитом на викладання, яке більше орієнтоване на розвиток компетенцій [12].

На необхідності залучення у процесі формування професійної компетентності студентів 3ВО всіх можливих “способів активізації резервних можливостей студента" наполягає М. Ярушак [8, 50].

Питання поліпшення якості надання освітніх послуг та пов'язані з цим педагогічні дослідження висвітлюються у численних аналітичних і наукових матеріалах, покликаних задовольнити вимоги сучасності щодо розвитку системи забезпечення якості освіти.

Формулювання мети і завдань статті. Мета статті полягає у дослідженні ситуації зі зворотним зв'язком при вивченні німецької мови студентами немовних 3ВО, а також взаємодії викладача зі студентом в рамках студентоорієнтованого підходу. Для цього булопроаналізовано опубліковані останнім часом вітчизняні та зарубіжні матеріали за відповідною тематикою і українські нормативно-правові акти. При підготовці статті були використані методи наукового дослідження: вивчення та теоретичний аналіз публікацій 3 педагогіки, методики викладання іноземних мов, нормативних документів.

Виклад основного матеріалу дослідження. У центрі сучасного процесу навчання перебуває студент з його цілями, потребами, інтересами та здібностями. Але щоб така система працювала 


\section{ВЗАЕМОДІЯ СТУДЕНТА ТА ВИКЛАДАЧАЯКОДИНЗІ ШЛЯХІВ ОПТИМІЗАЦІЇ НАВЧАННЯ ІНОЗЕМНИХ МОВ В ІНФОРМАЦИЙНОМУ СУСПІЛЬСТВІ}

3 максимальною ефективністю, необхідний якісний зворотний зв'язок, взаємодія викладача і студента. Під зовнішнім зворотним зв'язком розуміють контроль знань, способи обліку та оцінки результатів навчання викладачем. До внутрішнього зворотного зв'язку відносять отримання інформації про кінцеві результати навчання самими студентами.

Британською Радою в Україні був замовлений попередній аналіз потреб підвищення кваліфікації у сфері вищої освіти України, для чого влітку 2019 р. було проведене пілотне дослідження [11]. Завдяки участі у ньому викладачів та студентів були визначені ключові та нагальні напрями розвитку. Дослідники акцентували увагу на недостатності та майже повній відсутності використання на практиці сучасних, більш орієнтованих на студентів методик викладання та технологій для навчання. Шляхом опитування були зібрані дані стосовно навчальних ресурсів, практики викладання й оцінювання, використання технологій у навчанні та інші. За результатами опитування було з'ясовано, що більшість викладачів розробляють навчальні плани на основі власних знань та досвіду, причому менше 10 відсотків роблять це 3 урахуванням думки майбутніх роботодавців [11]. 3 огляду на наявні проблеми, пов'язані з працевлаштуванням випускників за отриманим фахом, цей показник $\epsilon$ дуже низьким. Також були отримані відповіді викладачів щодо оцінки того, наскільки викладання їх дисципліни допомагає студентам розвивати певні навички. Переважна більшість викладачів висловили впевненість, що в процесі викладання студенти набувають навичок командної роботи, розважливості та вміння приймати рішення, аналізувати інформацію, критично мислити та здатності до самостійного навчання. Щодо успішності розвитку у студентів навичок комплексного розв'язування задач або творчості позитивні відповіді надали дещо менше викладачів. Більшість респондентів вважала, що у проблемах, пов'язаних з розвитком практичних або технічних навичок, винні самі студенти, зокрема через відсутність у них належних зусиль або мотивації. У ході опитування окремі студенти висловили спостереження, що викладачі побоюються зворотного зв'язку, дехто завважив про необхідність додаткових годин для розвитку мовних навичок, практичних занять з іноземної (англійської) мови для спеціальних цілей $[11,12]$.

Невдовзі після вищезазначеного дослідження Британською Радою в Україні був підготовлений звіт за перший рік провадження Програми вдосконалення викладання у вищій освіті (2019-
2022) за підтримки Міністерства освіти і науки України та Національного агентства забезпечення якості вищої освіти [9]. За результатами звіту 93,3\% викладачів змінили свою практику оцінки набутих знань та умінь, яка проводиться у ході вивчення матеріалу (практику формативної оцінки) iз включенням використання питань, неформального зворотного зв'язку, самооцінки та взаємної оцінки, проведення спільних заходів [9]. 80 \% викладачів змінили свій підхід до підсумкових оцінок навчання студентів шляхом застосування більш різноманітних оцінних завдань, ефективнішого зворотного зв'язку, використання більш орієнтованих на студентів оцінних завдань [9]. Проте у звіті зазначається, що ті викладачі, хто не змінював практики, скаржились на нормативні обмеження [9]. С обнадійливим фактом, що 93,3\% опитаних викладачів мають намір для поліпшення викладання та навчання дізнаватися думки студентів та діяти з урахуванням їхніх відгуків або вже реалізують такий підхід на практиці [9].

Майже одночасно зі звітом про Програму вдосконалення викладання у вищій освіті у 2021 р. був затверджений професійний стандарт на групу професій “Викладачі закладів вищої освіти” [5]. Цим стандартом обумовлюються як загальні компетентності, так і перелік трудових функцій (професійних компетентностей), опис професійних кваліфікацій викладача закладу вищої освіти. Слід зазначити, що затверджений стандартом перелік умінь та навичок, якими повинен володіти викладач, вирізняється великим обсягом і визначає лінію підвищення кваліфікації викладачів. Серед професійних компетентностей привертає увагу здатність проводити заняття та забезпечувати досягнення результатів 3 урахуванням індивідуальних особливостей i потреб студентів, переглядати й оновлювати освітню програму відповідно до вимог внутрішньої системи забезпечення якості, потреб стейкхолдерів $[5,9]$. Стандартом обумовлюються, зокрема, такі уміння та навички, як збирання й аналіз відгуків та запитів студентів, роботодавців, інших стейкхолдерів щодо освітньої програми. Зворотний зв'язок передбачається як професійна компетентність, а саме як "здатність надавати студентам зворотний зв'язок щодо результатів оцінювання та рекомендації щодо покращення результатів навчання" [5, 11]. Видається цікавим, що затверджений стандарт отримав дуже обережну оцінку британських експертів, зокрема рецензія проєкту стандарту, підготовлена британським експертом, містила досить негативні відгуки [4].

Незважаючи на обмеження та зміни в 


\section{ВЗАЄМОДІЯ СТУДЕНТА ТА ВИКЛАДАЧА ЯК ОДИНЗІ ШЛЯХІВ ОПТИМІЗАЦІЇ НАВЧАННЯ ІНОЗЕМНИХ МОВ В ІНФОРМАЦИЙНОМУ СУСПІЛЬСТВІ}

організації навчального процесу, недостатність взаємодій між його учасниками освітнього процесу, обмеженість освітніх досліджень під час пандемії, робота над реформами вищої освіти та науки, впровадженням новітніх засобів навчання і виховання не припинялась. Д. Паркін, головний експерт з програм лідерства та менеджменту Advance HE, на відкритті форуму “Досконалість викладання і навчання у вищій освіті” у 2021 р. зазначив: "Викладачі повинні мати можливість ризикувати. Необхідно активно заохочувати їхню креативність, надавати необхідні інструменти для цього, винагороджувати успіхи та розвивати викладацький склад” [3, 3]. Учасниця форуму О. Яшенкова, доцентка кафедри англійської філології та міжкультурної комунікації Київського національного університету імені Тараса Шевченка зауважила, що без взаємодії зі студентами вона не уявляє викладацької діяльності: “Будь-який курс починається 3 того, що я дізнаюся про їхні очікування, вивчаю, хто вони і звідки. Бо як інакше дізнатися, як покращити власні курси?” [3]. Спираючись на власний досвід, вона переконана, що “конструктивна критика допомагає і стимулює викладача" [3]. За її словами, навчальний процес $€$ двостороннім і відповідальність за результативність повинні нести обидві сторони.

Викладачі мають бути відкриті до нових знань, адже досить часто буває так, що під час занять вони навчаються разом зі студентами. Попри більшу поінформованість сьогоднішніх студентів, їхня вправність у володінні сучасними інформаційно-комунікаційними технологіями, їх поточний рівень володіння іноземними мовами, 3 яким вони прийшли до ЗВО та який може виявитися досить високим з огляду на наявні сьогодні можливості вивчення мов, одним 3 головних завдань викладача залишається мотивування студента, навчання фільтрувати потоки інформації, займатися самоосвітою, а також стимулювати його до саморозвитку. За словами шведського поліглота та автора книги “Мистецтво вивчати мови” Е. Гуннемарка: "Важко переоцінити роль хорошого викладача, який вміє організувати систематичну роботу i підтримати самостійну працю учня. Навіть людина, яка давно і з задоволенням самостійно займається мовами, не може обійтися без звернення до викладачів ... " [1]. Найкращий результат взаємодії буде досягнуто у випадку, коли викладач враховує індивідуальні особливості студентів, їх особистий досвід, специфіку їхніх потреб та можливостей. При взаємодії викладача зі студентом необхідно орієнтуватися на підвищення активності здобувачів освіти, встановлення 3 ними зворотного зв'язку, створення доброзичливої атмосфери, яка сприятиме спільній та плідній праці. Розуміння мотивів студента, його спонуки до діяльності надає можливості для розробки ефективної системи навчання іноземної мови, зокрема, німецької мови як другої іноземної.

Висновки та перспективи подальших досліджень. На сьогодні особлива увага приділяється загальним та професійним компетентностям, професійним кваліфікаціям викладачів закладів вищої освіти. Ініціювання Програми вдосконалення викладання у вищій освіті привертає увагу до підвищення кваліфікації вчителів, поліпшення викладання та навчання. В Україні триває впровадження новітніх засобів навчання і виховання, зокрема методи активного навчання, що допомагають активізувати навчально-пізнавальну діяльність студентів. Якісний зворотний зв'язок, продуктивна взаємодія викладача і студента в процесі вивчення німецької мови розширюють можливості для розвитку i вдосконалення вмінь і навичок майбутніх фахівців та водночас сприяють розвитку у них додаткових компетенцій. Створення стійкої та комфортної взаємодії викладача і студента, доброзичливого освітнього середовища позитивно впливає на якість мовної підготовки, підвищує мотивацію вивчення іноземної мови, сприяє саморозвитку студента і розвиває його здатність до самоосвіти. Перспективним напрямом подальших наукових досліджень може бути вивчення аспектів взаємодії учасників освітнього процесу під час дистанційного навчання.

\section{ЛІТЕРАТУРА}

1. Гуннемарк Э.В. Искусство изучать языки. Санкт-Петербург: ТЕССА, 2002. 208 с.

2. Заруцкая Е. В. Формирование грамотности работы с обратной связью при обучении иностранному языку студентов высшей школы. Педагогика. Вопросы теории и практики. 2021. Том 6. Вып. 5. С. 849-854.

3. Звіт Форуму “Досконалість викладання i навчання у вищій освіті”. (17-18.03.2021). URL: https://www.britishcouncil.org.ua/sites/default/files/ teaching_excellence_forum_report.pdf (дата звернення: 20.11.2021).

4. Ніколаєв Є. Новий профстандарт - постріл в ногу університетських викладачів? (02.04.2021). URL: https://www.skeptic.in.ua/profstandard/ (дата звернення: 20.11.2021).

5. Про затвердження професійного стандарту на групу професій “Викладачі закладів вищої 


\section{ВЗАЕМОДІЯ СТУДЕНТА ТА ВИКЛАДАЧА ЯКОДИНЗІ ШЛЯХІВ ОПТИМІЗАЦЇ̈ НАВЧАННЯ ІНОЗЕМНИХ МОВ В ІНФОРМАЦИЙНОМУ СУСПІЛЬСТВІ}

освіти”. Наказ Мінекономіки України № 610 від 23.03.2021p. URL: https://ru.osvita.ua/legislation/ Vishya_osvita/81949/ (дата звернення: 20.11.2021).

6. Стратегія розвитку вищої освіти в Україні на 2021-2031 pp. / МОН України. Київ, 2020. 71 с.

7. Хаманн Г., Королева Н. Кто в наше время учит немецкий язык. (04.06.2020). URL: https:// www.dw.com/ru/кто-в-наше-время-учитнемецкий-язык/a-53675292 (дата звернення: 20.11.2021).

8. Ярушак М. Застосування компетентнісного підходу у процесі підготовки фахівців закладів вищої освіти. Молодь і ринок. 2021. № 9 (195). C. 47-51. doi: https://doi.org/10.24919/23084634.2021.243892.

9. British Council Ukraine. Teaching Excellence Programme Year 1. Report March 2021. URL: https:/ /www.britishcouncil.org.ua/sites/default/files/ bc_ukraine_tep_report_for_website.pdf (дата звернення: $20.11 . \overline{2021)}$.

10. Deutsch als Fremdsprache weltweit. Datenerhebung 2020. Auswaertiges Amt u. a. Paderborn, 2020. 56 p. URL: https://static.daad.de/media/daad_de/ pdfs_nicht_barrierefrei/der-daad/daad deutschlernerhebung_stand_04.06.2020.pdf (дата звернення: 20.11.2021).

11. Dexter B. Ukraine Higher Education Teaching Excellence Programme. Initial analysis. 2019. 26 p. URL: https://www.britishcouncil.org.ua/sites/default/ files/ukraine higher education _teaching_excellence_needs_analysis_report.pdf (дата звернення: 20.11.2021).

12. Hartung S. Zur Relevanz von AssessmentFeedback in der Hochschullehre. Zeitschrift für Hochschulentwicklung. 2009. Vol. 4. P. 1-22. doi:10.3217/zfhe-4-01/02.

\section{REFERENCES}

1. Gunnemark, E.V. (2002). Iskusstvo izuchat yazyki [The art and science of learning languages]. St.Petersburg, 208 p. [in Russian].

2. Zarutckaia, E. V. (2021). Formirovanie gramotnosti raboty s obratnoy svyazyu pri obuchenii inostrannomu yazyku studentov vysshey shkoly [Developing University Students' Feedback Literacy When Teaching a Foreign Language]. Pedagogy. Theory \& Practice. Vol. 6, Issue 5, pp. 849-854. [in Russian].

3. Forum Report "Doskonalist vykladannia i navchannia u vyshchii osviti" (17-18.03.2021). ["Higher Education Teaching and Learning Excellence"]. (Accessed 20 Nov. 2021). Available at: https://www.britishcouncil.org.ua/sites/default/ files/teaching_excellence_forum_report.pdf [in Ukrainian].

Молодь і ринок №11-12 (197-198), 2021
4. Nikolaiev, Ye. (2021). Novyi profstandart postril v nohu universytetskykh vykladachiv? [New professional standard - a shot in the foot of university teachers?]. (Accessed 20 Nov. 2021). Available at: https://www.skeptic.in.ua/profstandard/ [in Ukrainian].

5. Pro zatverdzhennia profesiinoho standartu na hrupu profesii "Vykladachi zakladiv vyshchoi osvity" [On approval of the professional standard for the group of professions "Teachers of higher education institutions"]. Order of the Ministry of Economy of Ukraine N 610 of March 23, 2021. Available at: https:/ /ru.osvita.ua/legislation/Vishya_osvita/81949/ (Accessed 20 Nov. 2021). [in Ukrainian].

6. Stratehiia rozvytku vyshchoi osvity v Ukraini na 2021-2031 roky [Strategy for the development of higher education in Ukraine for 2021-2031]. Ministry of Education and Science of Ukraine. 71 p. [in Ukrainian].

7. Hamann, G. \& Koroleva, N. (2020). Kto v nashe vremya uchit nemetskiy yazyk [Who is currently studying German]. Available at: https:// www.dw.com/ru/кто-в-наше-время-учитнемецкий-язык/a-53675292 (Accessed 20 Nov. 2021). [in Russian].

8. Yarushak, M. (2021). Zastosuvannia kompetentnisnoho pidkhodu u protsesi pidhotovky fakhivtsiv zakladiv vyshchoi osvity [Application of competence approach in the process of training professionals of higher education institutions]. Youth and market. Vol. 9 (195), pp. 47-51. doi: https:// doi.org/10.24919/2308-4634.2021.243892 [in Ukrainian].

9. British Council Ukraine. Teaching Excellence Programme Year 1. Report 2021. Available at: https:/ /www.britishcouncil.org.ua/sites/default/files/ bc_ukraine_tep_report_for_website.pdf[in English].

10. Deutschals Fremdsprache weltweit. Datenerhebung 2020 [German as a foreign language around the world]. Auswaertiges Amt u. a. Paderborn, 56 p. Available at: https://static.daad.de/media/daad_de/pdfs $\mathrm{nicht}$ b arrierefre i/der-d a a d daad_deutschlernerhebung_stand_04.06.2020.pdf (Accessed 20 Nov. 2021). [in German].

11. Dexter, B. (2019). Ukraine Higher Education Teaching Excellence Programme. Initial analysis. 26 p. Available at: https://www.britishcouncil.org.ua/ sites/default/files/ ukraine higher_education teaching_excellence_needs_analysis_report.pdf (Accessed 20 Nov. 2021). [in English].

12. Hartung, S. (2009). Zur Relevanz von Assessment-Feedback in der Hochschullehre [The relevance of feedback assessment in university teaching]. Journal of University Development. Vol. 4, pp. 1-22. doi:10.3217/zfhe-4-01/02. [in German].

Стаття надійшла до редакції 09.11.2021 